\title{
Effect of changes in FSH induced by bovine follicular fluid and FSH infusion in the preovulatory phase on subsequent ovulation rate and corpus luteum function in the ewe
}

\author{
A. S. McNeilly \\ M.R.C. Reproductive Biology Unit, University of Edinburgh, Centre for Reproductive Biology, \\ 37 Chalmers Street, Edinburgh EH3 9EW, U.K.
}

\begin{abstract}
Summary. Treatment of Damline ewes with i.v. injections of various doses $(2,5$ or 10 $\mathrm{ml}$ ) of bovine follicular fluid for $72 \mathrm{~h}$ after prostaglandin-induced luteal regression resulted in a significant decrease in plasma concentrations of FSH after a 1.5-2 h delay but did not affect $\mathrm{LH}$. The half life of this decrease in plasma FSH levels (156 min) after injection of follicular fluid was similar to that for clearance $(159 \mathrm{~min})$ of ovine FSH after infusion. A significant rebound increase in plasma FSH levels occurred by $13 \mathrm{~h}$ after all follicular fluid injections, and the magnitude of this rebound was inversely related to the dose of follicular fluid injected. A significant delay in the onset of oestrus occurred only with 5 and $10 \mathrm{ml}$ bovine follicular fluid. There was no significant effect on ovulation rate or subsequent corpus luteum function as measured by plasma concentrations of progesterone. Infusion of ovine FSH $(50 \mu \mathrm{g} / \mathrm{h}$ for $48 \mathrm{~h})$ during the period of follicular fluid treatment prevented the delay in onset of oestrus and resulted in a substantial (2-10-fold) increase in ovulation rate. Corpus luteum function in terms of progesterone secretion was also enhanced. These results show that (1) intermittent suppression of FSH during the preovulatory period in the ewe does not affect subsequent ovulation rate or corpus luteum function and (2) the delay in the onset of oestrus induced by bovine follicular fluid can be prevented by exogenous FSH.
\end{abstract}

\section{Introduction}

The injection of bovine follicular fluid for 48 or $72 \mathrm{~h}$ after prostaglandin-induced luteal regression resulted in a significant delay in the onset of oestrus (Miller, Crister, Rowe \& Ginther, 1979; McNeilly, 1984). During this delay plasma concentrations of FSH were reduced after injection of follicular fluid but increased significantly above that of controls at the end of treatment (Miller, Crister \& Ginther, 1982; McNeilly, 1984). In contrast there were no significant effects of treatment with bovine follicular fluid on basal plasma values of LH (Miller et al., 1982; McNeilly, 1984) or pulse frequency or amplitude of LH secretion (McNeilly, 1984). Corpus luteum function, in terms of plasma concentrations of progesterone, was apparently normal (McNeilly, 1984) but effect on ovulation rate was not otherwise determined.

The precise role of FSH in the control of follicular growth and ovulation rate remains unclear (Baird \& McNeilly, 1981; McNatty, 1982; Baird, 1983; Scaramuzzi \& Radford, 1983). In the present study various doses of bovine follicular fluid were injected during the preovulatory period in an attempt to induce different degrees of suppression of FSH. The effect of this on ovulation rate was assessed subsequently by laparoscopy. Ewes were also infused with FSH to maintain constant plasma levels during the period of treatment with bovine follicular fluid. 


\section{Materials and Methods}

Animals

Thirty Damline ewes (47\% Finnish Landrace, 24\% East Friesland, 17\% Border Leicester, 12\% Dorset Horn; 2 or 3 years old ; 47-55 kg) were used in 2 experiments in November. Throughout the experiments animals were kept in metabolism crates $(0.5 \times 1 \mathrm{~m})$ in a heated room (about $\left.15^{\circ} \mathrm{C}\right)$ under natural lighting conditions at Dryden Field Station, Roslin, Midlothian, U.K. Ewes had access to food and water ad libitum.

\section{Experimental design}

Before each experiment, ewes were treated with progesterone-impregnated vaginal sponges (Chronogest: Intervet Laboratories, Cambridge, U.K.) to synchronize cycles. Experiments were performed during the subsequent natural cycles.

Experiment 1. At $09: 00 \mathrm{~h}$ on Day 10, luteal regression was induced in all ewes by i.m. injection of $100 \mu \mathrm{g}$ cloprostenol, a potent analogue of prostaglandin (PG) F-2 $\alpha$ (Estrumate: ICI, Cheshire, U.K.). Then groups of 5 ewes each were given i.v. injections of 2,5 or $10 \mathrm{ml}$ charcoal-treated bovine follicular fluid collected and prepared exactly as described previously (McNeilly, 1984), at the same time as the PG $(09: 00 \mathrm{~h})$ and again at 17:00 $\mathrm{h}$ on Day 1, with further treatment at 09:00 $\mathrm{h}$ and $17: 00 \mathrm{~h}$ on Days 2 and 3 after cloprostenol. Five ewes were injected with $10 \mathrm{ml}$ saline $(9 \mathrm{~g} \mathrm{NaCl} / \mathrm{l})$ in place of bovine follicular fluid and acted as controls.

Blood samples $(3 \mathrm{ml})$ were withdrawn via indwelling jugular catheters, inserted the previous day, at 30-min to $1-\mathrm{h}$ intervals from $1 \mathrm{~h}$ before until $8 \mathrm{~h}$ after cloprostenol injection and at similar intervals between $23-32.5$ and $46-56.5 \mathrm{~h}$ after cloprostenol. In addition, 15-min blood samples were withdrawn over a $3-\mathrm{h}$ period $26-29 \mathrm{~h}$ after cloprostenol to allow measurement of pulsatile secretion of $\mathrm{LH}$.

From $32 \mathrm{~h}$ after cloprostenol injection the ewes were tested every $8 \mathrm{~h}$ for response to a raddled vasectomized ram to detect oestrus. At each test, the ewes were removed from the metabolism crates and observed in a pen with a vasectomized ram for $5 \mathrm{~min}$. Once oestrus had been detected, blood samples were collected every 2 days for 11 days and plasma progesterone concentrations were measured to assess the function of the corpus luteum. Ovulation rate was determined by laparoscopic examination of the ovaries under halothene anaesthesia for corpora lutea between Days 6 and 7 after detection of oestrus.

Experiment 2. The 5 control ewes in Exp. 1 and 10 previously synchronized ewes not used in Exp. 1 were used to study the effect of simultaneous infusion of ovine FSH on the delay in oestrus caused by the injection of bovine follicular fluid. Ten ewes were given i.v. injections of $5 \mathrm{ml}$ bovine follicular fluid at the same time as the cloprostenol $(09: 00 \mathrm{~h})$ on Day 10 of the luteal phase, and again at 17:00 $\mathrm{h}$ on Day 1 with further treatment at 09:00 $\mathrm{h}$ and 17:00 $\mathrm{h}$ on Day 2 after cloprostenol. Five of these ewes were given an i.v. infusion of $50 \mu \mathrm{g}$ ovine FSH (NIAMDD-oFSH$14) / \mathrm{h}$ for $48 \mathrm{~h}$ from the time of cloprostenol injection. For infusion, a stock of ovine FSH $(2.5 \mathrm{mg} / \mathrm{ml}$ sterile saline $(9 \mathrm{~g} \mathrm{NaCl} / \mathrm{l}))$ was prepared and diluted in saline $(9 \mathrm{~g} \mathrm{NaCl} / \mathrm{l})$ containing $6 \%$ plasma previously obtained from each ewe. Infusions were given via a cannula in the jugular vein contralateral to that used for collecting blood samples, using Harvard infusion pumps (Harvard Apparatus Co., Millis, MA, U.S.A.) at an infusion rate of $1.8 \mathrm{ml} / \mathrm{h}$. Ewes not receiving ovine FSH were infused with $0.9 \%$ saline as a control and the 5 ewes not receiving bovine follicular fluid injections were injected with $5 \mathrm{ml}$ saline and acted as controls.

Collection of blood samples, detection of oestrus and subsequent assessment of ovulation rate was the same as in Exp. 1. All blood samples in both experiments were collected into heparinized tubes (10 U heparin/ml blood; Leo Laboratories Ltd, Aylesbury, Bucks, U.K.). Samples were centrifuged and plasma was stored at $-20^{\circ} \mathrm{C}$ until hormone assays were performed. 


\section{Hormone assays}

LH and FSH were measured in duplicate using specific double-antibody radioimmunoassays exactly as described previously (McNeilly, McNeilly, Walton \& Cunningham, 1976; Martensz, Baird, Scaramuzzi \& Van Look, 1976). The sensitivities of the assays were $0 \cdot 1 \mathrm{ng} \mathrm{LH} \mathrm{(NIH-LH-}$

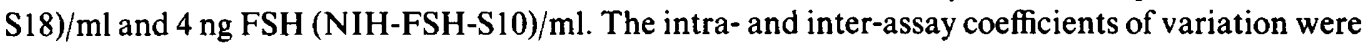
$5.5 \%$ and $7.4 \%$ for $\mathrm{LH}$ and $4.8 \%$ and $9.9 \%$ for FSH.

Progesterone concentrations in plasma were measured by the radioimmunoassay described previously (Djahanbahkch, Swanston, Corrie \& McNeilly, 1981) with an intra-assay coefficient of variation of $8.8 \%$ and sensitivity of $0.1 \mathrm{ng} / \mathrm{ml}$. Recovery of progesterone added to sheep plasma was $75 \pm 4 \%$ (s.e.m., $n=30$ ).

\section{Statistical analysis}

The effects of treatment on onset of oestrus and characteristics of the pulsatile secretion of LH were analysed by Student's $t$ test. Ovulation rate was analysed using the $\chi^{2}$ test. The differences in hormone levels during treatment with bovine follicular fluid were compared by Student's $t$ test using for comparison the plasma levels over the $1-\mathrm{h}$ period before each injection of bovine follicular fluid on each day of treatment and the levels $7-9 \mathrm{~h}$ after each injection. Regression analysis was applied to changes in the plasma levels of FSH after bovine folicular fluid or saline injection.

\section{Results}

\section{Oestrus, ovulation rate and luteal function}

The treatment of ewes with 5 or $10 \mathrm{ml}$ bovine follicular fluid for $72 \mathrm{~h}$ (Exp. 1) or $5 \mathrm{ml}$ for $48 \mathrm{~h}$ (Exp. 2) after cloprostenol injection resulted in a significant delay in the onset of oestrus (Table 1). In contrast, injection with $2 \mathrm{ml}$ was without significant effect. The injection of bovine follicular fluid in both experiments did not affect ovulation rate (Table 1) or plasma concentrations of progesterone in the luteal phase (Exp. 1, Table 1; Exp. 2, Text-fig. 1).

The infusion of FSH during the period of treatment with bovine follicular fluid (Exp. 2) prevented the delay in onset of oestrus, which occurred at the same time as control animals (Table 1), and resulted in a significant increase in ovulation rate (Table 1) which was matched by

Table 1. Effect of treatment of ewes with different volumes of bovine follicular fluid (BFF) for $72 \mathrm{~h}$ and BFF with and without concomitant infusion of ovine FSH for $48 \mathrm{~h}$ after cloprostenol-induced luteal regression on Day 10 of the luteal phase

\begin{tabular}{|c|c|c|c|c|c|c|}
\hline \multirow[b]{2}{*}{ Exp } & \multicolumn{3}{|c|}{ Treatment } & \multirow[b]{2}{*}{$\begin{array}{l}\text { Time of oestrus } \\
\text { (h) }\end{array}$} & \multirow[b]{2}{*}{$\begin{array}{l}\text { Ovulation } \\
\text { rate }\end{array}$} & \multirow[b]{2}{*}{$\begin{array}{l}\text { Progesterone conc. } \\
\text { on Day } 10(\mathrm{ng} / \mathrm{ml})\end{array}$} \\
\hline & $\begin{array}{l}\text { BFF vol. } \\
\text { (ml) }\end{array}$ & FSH & $\begin{array}{l}\text { Duration } \\
\text { (h) }\end{array}$ & & & \\
\hline 1 & $\begin{array}{r}0 \\
2 \\
5 \\
10\end{array}$ & $\begin{array}{l}- \\
- \\
- \\
-\end{array}$ & $\begin{array}{l}\overline{72} \\
72 \\
72\end{array}$ & $\begin{array}{c}53 \pm 2 \\
61 \pm 4 \\
117 \pm 16^{*} \\
134 \pm 12^{* *}\end{array}$ & $\begin{array}{l}2.6 \pm 0.3 \\
2.2 \pm 0.2 \\
2.6 \pm 0.7 \\
1.8 \pm 0.2\end{array}$ & $\begin{array}{l}4.35 \pm 0.47 \\
3.60 \pm 0.44 \\
3.85 \pm 0.21 \\
3.45 \pm 0.44\end{array}$ \\
\hline 2 & $\begin{array}{l}0 \\
5 \\
5\end{array}$ & $\begin{array}{l}- \\
\overline{+}\end{array}$ & $\begin{array}{l}48 \\
48 \\
48\end{array}$ & $\begin{array}{l}45 \pm 2 \\
73 \pm 5^{*} \\
43 \pm 2\end{array}$ & $\begin{aligned} 2 \cdot 9 & \pm 0 \cdot 3 \\
3 \cdot 4 & \pm 1 \cdot 0 \\
14 \cdot 6 & \pm 2 \cdot 6^{* *}\end{aligned}$ & $\begin{array}{c}4.53 \pm 0.41 \\
5.22 \pm 0.74 \\
11.76 \pm 1.99^{* *}\end{array}$ \\
\hline
\end{tabular}

Values are mean \pm s.e.m. for 5 ewes. rate).

Compared to control: ${ }^{*} P<0.005,{ }^{* *} P<0.001$ (Student's $t$ test for oestrus and progesterone; $\chi^{2}$ test for ovulation 


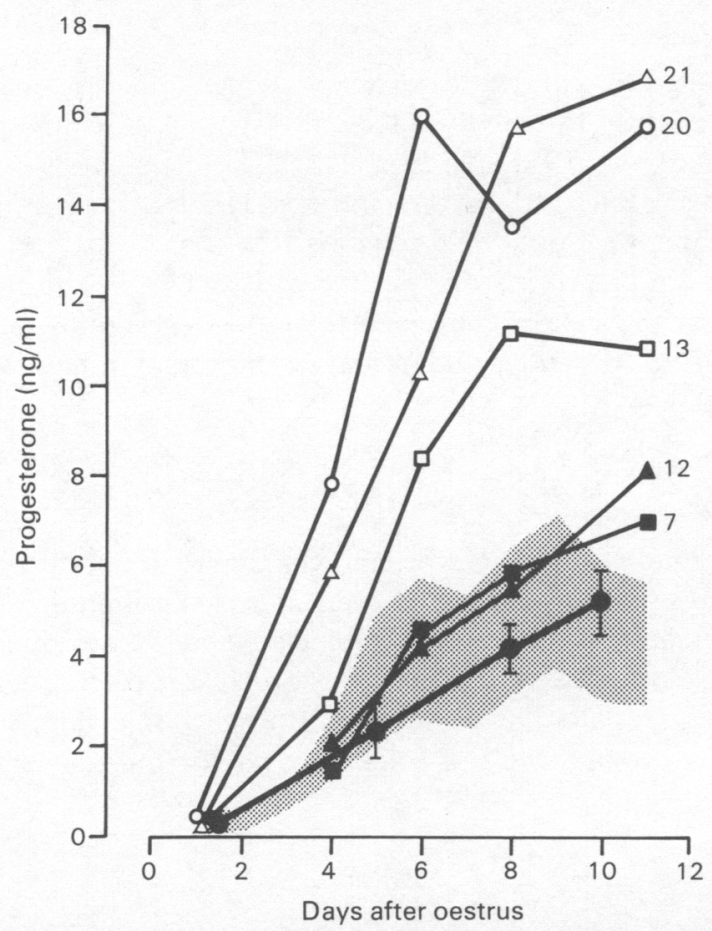

Text-fig. 1. Changes in the concentration of progesterone after oestrus in ewes treated with i.v. injections of bovine follicular fluid alone (O, mean \pm s.e.m. $N=5)$ and in individual ewes $(O$, $\triangle, \square, \mathbf{D}, \Delta$ ) treated with bovine follicular fluid and infused with ovine FSH for $48 \mathrm{~h}$ after cloprostenol-induced luteal regression. The range $( \pm 1$ s.d.) of changes in concentration of progesterone in control saline-treated ewes is shown by the stippled area. The numbers indicate the ovulation rate of the individual ewes.

substantially elevated plasma progesterone concentrations at least up to Day 12 of the oestrous cycle in 3 of the 5 ewes treated with FSH (Text-fig. 1).

\section{Concentrations of FSH and $L H$}

FSH. In Exp. 1 the injection of bovine follicular fluid at $09: 00 \mathrm{~h}$ on Days 1,2 and 3 resulted in a significant decrease in FSH over the 8-h period after injection on each day (Text-fig. 2). Plasma concentrations of FSH 7-9 h after the $09: 00 \mathrm{~h}$ injection of bovine follicular fluid on each of these days were significantly $(P<0.001)$ lower than in control ewes (Text-fig. 2$)$ and there was no significant difference in these FSH concentrations in ewes injected with different volumes of follicular fluid.

The decline in FSH concentrations occurred 1.5-2.5 h after the 09:00 $\mathrm{h}$ injection of bovine follicular fluid and the subsequent rate of decline was similar on Days 1-3 and with 2,5 and $10 \mathrm{ml}$ bovine follicular fluid. The half-life of this decrease in FSH in individual animals was calculated on each day from the first time levels decreased from the plateau concentrations around the time of bovine follicular fluid injection to the basal levels 7-9 h later. This half-life did not differ significantly within animals on each of Days 1-3 or between animals in relation to the volume of bovine follicular fluid injected. The overall half-life of decrease in FSH after bovine follicular fluid injection was $156 \mathrm{~min}$ (range $120-190 ; n=45$ ).

In the ewes receiving bovine follicular fluid, FSH concentrations in the hour before follicular fluid injection at $09: 00 \mathrm{~h}$ were significantly higher $(P<0.05$ to $P<0.001)$ than in control ewes on 


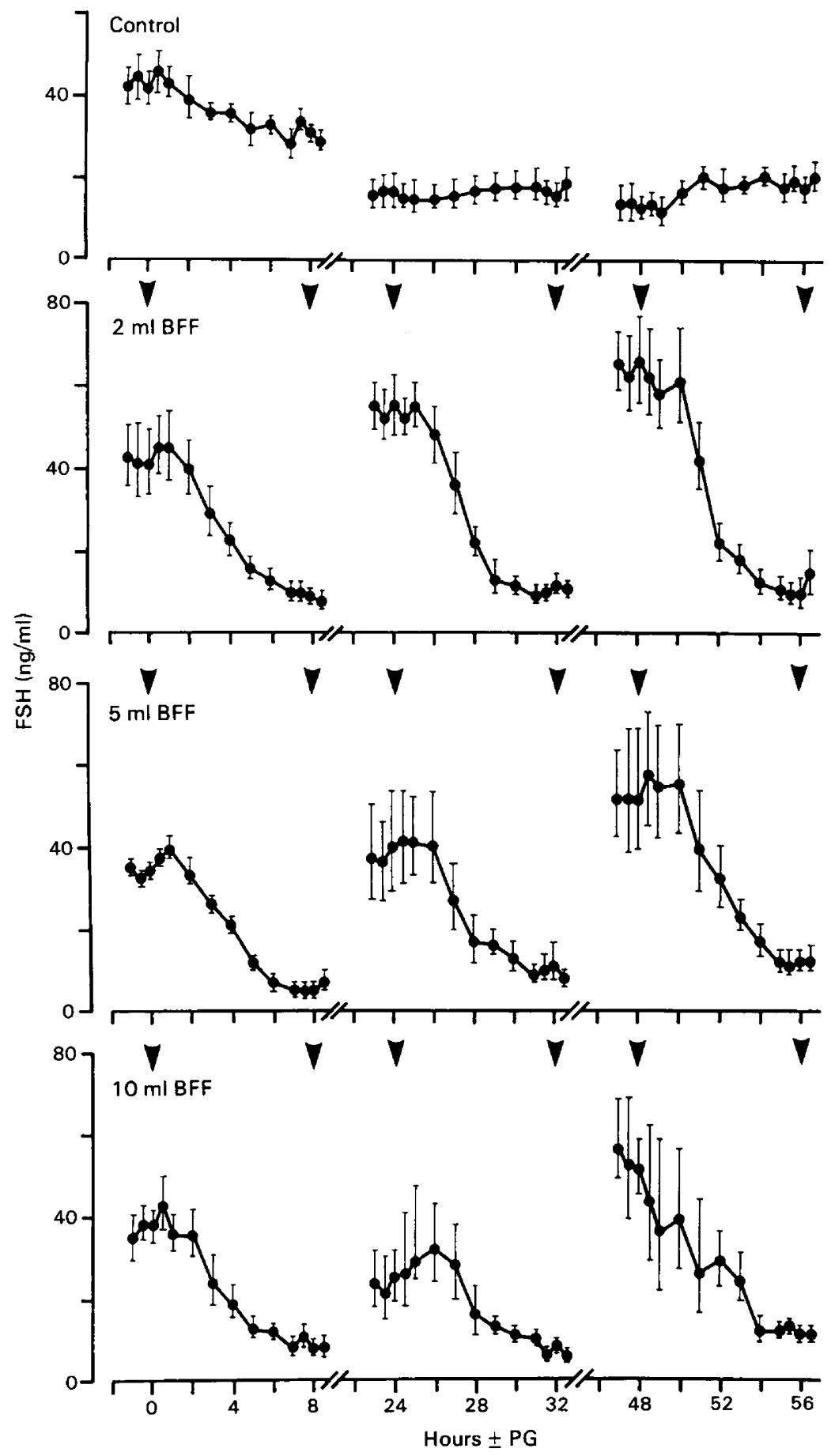

Text-fig. 2. Changes (mean \pm s.e.m., 5 ewes/group) in the concentrations of FSH after cloprostenol-induced (PG) luteal regression in control saline-treated ewes or ewes treated with i.v. injections $(\nabla)$ of 2,5 or $10 \mathrm{ml}$ bovine follicular fluid. 
both Days 2 and 3 after cloprostenol. The one exception was on Day 2 in ewes receiving $10 \mathrm{ml}$ follicular fluid and the increase just failed to achieve significance. FSH concentrations were greater in inverse relation to the volume of follicular fluid being injected. A similar rebound increase in FSH concentrations was apparent on Day 4 in ewes not showing oestrous behaviour (data not shown).

In Exp. 2 the injection of $5 \mathrm{ml}$ bovine follicular fluid resulted in a similar change in plasma levels of FSH to those described above (data not shown). Infusion of FSH resulted in a substantial increase in FSH concentrations to levels of $202 \pm 9 \mathrm{ng} / \mathrm{ml}$ ( \pm s.e.m.) on Day 1 and $301 \pm 5 \mathrm{ng} / \mathrm{ml}$ on Day 2. When the infusion was stopped at $09: 00 \mathrm{~h}$ on Day 3, plasma concentrations of FSH declined in all animals with a mean half-life of $159 \mathrm{~min}$ (range $120-230 \mathrm{~min} ; n=5$ ).

$L H$. There were no significant differences between plasma concentrations of LH in control or treated ewes throughout the preovulatory period although LH concentrations tended to be higher in ewes receiving bovine follicular fluid (Text-fig. 3). Analysis of the pulsatile secretion of LH 26-29 h after cloprostenol failed to show any difference in pulse frequency $(1.25-1.36 \mathrm{pulses} / \mathrm{h})$ or pulse amplitude in Exp. 1 (control, $1.7 \pm 0.4 \mathrm{ng} / \mathrm{ml}$; bovine follicular fluid: $2 \mathrm{ml}, 1.85 \pm 0.2 \mathrm{ng} / \mathrm{ml} ; 5 \mathrm{ml}$, $2.56 \pm 0.33 \mathrm{ng} / \mathrm{ml} ; 10 \mathrm{ml}, 2.66 \pm 0.36 \mathrm{ng} / \mathrm{ml})$.

In Exp. 2, plasma values and pulsatile secretion of LH were not significantly affected by treatment with bovine follicular fluid or concomitant infusion of FSH.

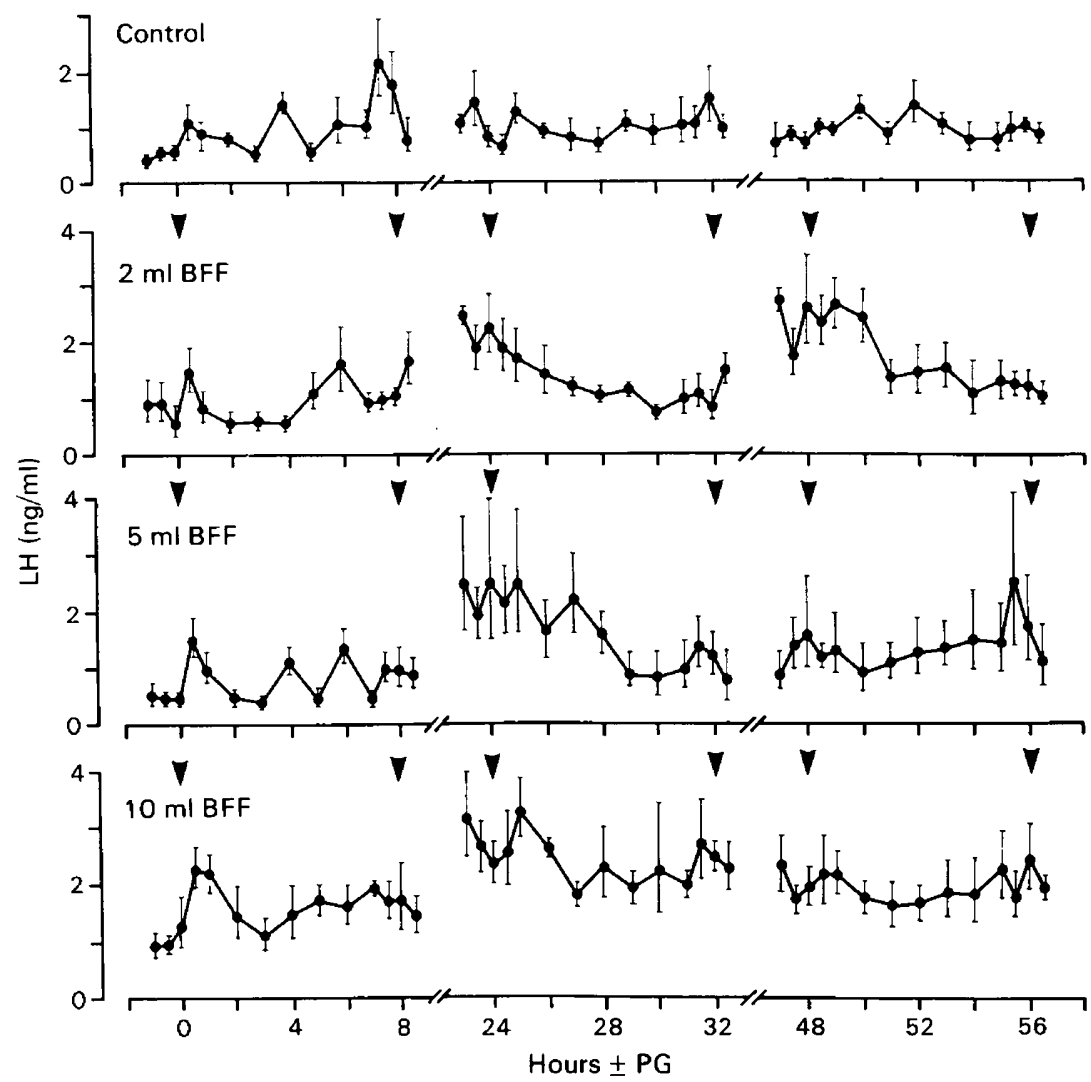

Text-fig. 3. Changes (mean \pm s.e.m., 5 ewes/group) in the concentrations of LH after cloprostenol-induced (PG) luteal regression in control saline-treated ewes or ewes treated with i.v. injections $(\boldsymbol{V})$ of 2,5 or $10 \mathrm{ml}$ bovine follicular fluid. 


\section{Discussion}

The present study has confirmed that injections of bovine follicular fluid during the preovulatory phase in the ewe will suppress plasma concentrations of FSH and delay the onset of oestrus (Miller et al., 1979; McNeilly, 1984). However, it has now been shown that this delay depends on the dose of bovine follicular fluid given and, regardless of whether there is a delay in oestrus, these induced alterations in plasma FSH values during the preovulatory phase do not affect the number of follicles ovulating or the function of the resulting corpora lutea. In addition it was further confirmed that bovine follicular fluid did not affect the secretion of LH during the preovulatory phase.

The FSH response to bovine follicular fluid was after each injection similar to that described previously (Cummins, O'Shea, Bindon, Lee \& Findlay, 1983; McNeilly, 1984) with a 1·5-2-h delay after injection before FSH levels began to decrease. The half-time of this decrease in FSH levels over the following 7-9 h period was $156 \mathrm{~min}$, remarkably close to the half-time of clearance (159 min) of FSH when the infusion was stopped in Exp. 2. This clearly suggests that the active component in bovine follicular fluid, probably inhibin (de Jong \& Sharpe, 1976), acts at the pituitary to inhibit the release of FSH for a prolonged period (see Baker et al., 1983). Why there is a delay before this inhibition of release occurs is unknown. The duration of the inhibition was related to the dose of bovine follicular fluid injected since the magnitude of the rebound in FSH over the 16 $\mathrm{h}$ between injections on each day was inversely related to the dose (Text-fig. 2). Thus between 25 and $26 \mathrm{~h}$ after the first injection of bovine follicular fluid, plasma FSH levels were significantly higher in ewes receiving $2 \mathrm{ml}$ bovine follicular fluid than in those receiving 5 or $10 \mathrm{ml}$. This may explain why there was no significant delay in the onset of oestrus in the $2 \mathrm{ml}$ group since the overall duration of exposure to lower than normal plasma levels of FSH was presumably less than that for the 5 or $10 \mathrm{ml}$ groups.

It remained possible that the delay in oestrus, presumed to result from a failure of follicles to secrete oestradiol (McNeilly, 1984), may have been caused by a component in the bovine follicular fluid acting directly on the ovary, rather than an indirect effect via alterations in the pattern of FSH secretion. Treatment of ewes with ovine follicular fluid resulted in a significant reduction in follicular development induced by the injection of PMSG (Cahill, Clarke, Cummins \& Findlay, 1984). However, in the present experiments infusion of highly purified ovine FSH counteracted any effect of bovine follicular fluid on the delay of oestrus, and therefore presumably on follicular development. Indeed, there was a substantial increase in ovulation rate in ewes receiving FSH as well as bovine follicular fluid, and in terms of progesterone secretion the resulting corpora lutea appeared to be normal. The dramatic increase in ovulation rate is almost certainly related to the substantial (10-20-fold) increase in plasma concentrations of FSH during infusion, indicating that the dose of FSH infused was excessive. A similar increase in ovulation rate occurs when FSH is given by injection (Wright, Bondioli, Grammer, Kuzan \& Menimo, 1981). Nevertheless, these results indicate that during the preovulatory phase many follicles can develop into normal preovulatory follicles and the number developing in the normal preovulatory period may be dependent on the plasma concentration of FSH during this time (Baird, 1983). This further suggests that the preovulatory follicle(s) can be selected from any of the pool of follicles available at the time of luteal regression (McNatty, 1982; Coleman \& Dailey, 1983; Driancourt \& Cahill, 1984; Tsonis, Cahill, Carson \& Findlay, 1984) although whether FSH is primarily responsible for this selection remains to be resolved.

I thank Miss N. Anderson, Miss M. Fordyce, Miss S. Gunn and Mr B. Ogilvie for skilled technical assistance; the staff at Dryden Field Station; the NIADDK (Bethesda, Maryland, U.S.A.), Dr S. S. Lynch and Dr J. E. T. Corrie for hormones and antiserum used in the radioimmunoassays; $\mathrm{Mr} \mathrm{T}$. McFetters and $\mathrm{Mr}$ E. Pinner for preparation of the figures; Mrs $\mathrm{P}$. Warner for statistical advice; and Miss A. Wallace for typing the manuscript. 


\section{References}

Baird, D.T. (1983) Factors regulating the growth of the preovulatory follicle in the sheep and human. $J$. Reprod. Fert. 69, 343-352.

Baird, D.T. \& McNeilly, A.S. (1981) Gonadotrophic control of follicular development and secretion in the sheep oestrous cycle. J. Reprod. Fert., Suppl. 30, 119133.

Baker, H.W.G., Burger, H.G., de Kretser, D.M., Findlay, J.K., Hudson, B., Lee, V.W.K. \& Tsonis, C. (1983) Present status of research on inhibin: an appraisal. Clin. Reprod. Fert. 2, 161-174.

Cahill, L.P., Clarke, I.J., Cummins, J.T. \& Findlay, J.K. (1984) Direct inhibition of follicular growth by steroid-free follicular fluid. Proc. Aust. Soc. Reprod. Biol. 16, Abstr. 21 .

Coleman, D.A. \& Dailey, R.A. (1983) Effects of repeated removal of large ovarian follicles and treatment with progestin on ovarian function in the ewe. Biol. Reprod. 29, 586- 593.

Cummins, L.J., O'Shea, T., Bindon, B.M., Lee, V.W.K. \& Findlay, J.K. (1983) Ovarian inhibin content and sensitivity to inhibin in Booroola and control strain Merino ewes. J. Reprod. Fert. 67, 1-7.

de Jong, F.H. \& Sharpe, R.M. (1976) Evidence for inhibin-like activity in bovine follicular fluid. Nature, Lond. 263, 71-72.

Djahanbahkch, O., Swanston, I.A., Corrie, J.E.T. \& McNeilly, A.S. (1981) Prediction of ovulation by progesterone. Lancet ii, 1164-1165.

Driancourt, M.A. \& Cahill, L.P. (1984) Preovulatory follicular events in sheep. J. Reprod. Fert. 71, 205211.

Martensz, N.D., Baird, D.T., Scaramuzzi, R.J. \& Van Look, P.F.A. (1976) Androstenedione and the control of luteinizing hormone in the ewe during anoestrus. $J$. Endocr. 69, 227-237.
McNatty, K.P. (1982) Ovarian follicular development from the onset of luteal regression in human and sheep. In Follicular Maturation and Ovulation, pp. 118. Eds R. Rolland, E. V. van Hall, S. G. Hillier, K. P. McNatty \& J. Schoenmaker. Excerpta Medica, Amsterdam.

McNeilly, A.S. (1984) Changes in FSH and the pulsatile secretion of LH during the delay in oestrus induced by treatments of ewes with bovine follicular fluid. $J$. Reprod. Fert. 72, 165-172.

McNeilly, J.R., McNeilly, A.S., Walton, J.S. \& Cunningham, F.J. (1976) Development and application of a heterologous radioimmunoassay for ovine follicle stimulating hormone. J. Endocr. 70, 69-79.

Miller, K.F., Crister, J.K., Rowe, R.F. \& Ginther, O.J. (1979) Ovarian effects of bovine follicular fluid treatment in sheep and cattle. Biol. Reprod. 21, 537544.

Miller, K.F., Crister, J.K. \& Ginther, O.J. (1982) Inhibition and subsequent rebound of FSH secretion following treatment with bovine follicular fluid in the ewe. Theriogenology 18, 45-53.

Scaramuzzi, R.J. \& Radford, H.M. (1983) Factors regulating ovulation rate in the ewe. J. Reprod. Fert. 69, 353-367.

Tsonis, C.G., Cahill, L.P., Carson, R.S. \& Findlay, J.K. (1984) Identification at the onset of luteolysis of follicles capable of ovulation in the ewe. J. Reprod. Fert. 70, 609-614.

Wright, R.W., Jr, Bondioli, K., Grammer, J., Kuzan, F. \& Menino, A., Jr (1981) FSH or FSH plus LH superovulation in ewes following estrus synchronization with medroxyprogesterone acetate pessaries. $J$. Anim. Sci. 52, 115-118.

Received 19 November 1984 